\title{
Telaah Yuridis terhadap Pengaturan Restorative Justice di Kepolisian
}

\author{
Rena Yulia dan Aliyth Prakarsa \\ Dosen Fakultas Hukum, Universitas Sultan Ageng Tirtayasa \\ Jalan Palka Sindangsari, Serang, Banten. \\ Email: renayulia@untirta.ac.id,prakarsa@untirta.ac.id
}

\begin{abstract}
Abstrak. Institusi Kepolisian merupakan gerbang pertama dan utama dalam upaya penegakan hukum. Pertama, institusi kepolisian yang bertugas melakukan setiap penegakan kasus pidana, kemudian akan ditentukan tahap selanjutnya oleh pihak kepolisian. Praktek penegakan hukum selama ini cenderung bersifat retributive justice, sehingga sedikit kasus yang dapat diselesaikan dalam proses penyidikan polisi. Keadilan restoratif muncul dengan menawarkan berbagai keuntungan, antara lain proses penyelesaian menjadi sederhana, dengan melibatkan kedua belah pihak, baik pelaku maupun korban, dan adanya peran pihak ketiga untuk mendamaikan, sehingga perkara dapat diselesaikan sesuai kesepakatan. Kepolisian, sebagai institusi pertama dalam proses penegakan hukum telah membuat surat edaran terkait penerapan restorative justice, sebagai wujud perubahan dari penegakan hukum bersifat retributif. Penelitian ini bertujuan menelaah secara yuridis pengaturan restorative justice di tingkat kepolisian seiring dengan pemberlakuan Surat Edaran Kapolri Nomor: SE/8/VII/2018 tentang Penerapan Keadilan Restoratif (Restorative Justice) dalam Penyelesaian Perkara Pidana dan Peraturan Kepala Kepolisian RI Nomor 6 Tahun 2019 tentang Penyidikan Tindak Pidana. Penelitian ini menggunakan metode penelitian kualitatif dengan jenis penelitian hukum normatif melalui pendekatan perundang-undangan
\end{abstract}

Kata kunci: korban, pelaku, kepolisian, restorative

\begin{abstract}
Police institutions are the first and main gate in law enforcement efforts. First, the police institution in charge of carrying out each criminal case's enforcement, then the next stage will be determined by the police. The practice of law enforcement so far tends to be retributive justice, so that only a few cases can be resolved in the police investigation process. Restorative justice appears by offering various advantages, including a simple settlement process, involving both parties, both perpetrators and victims, and the role of a third party to mediate, so that cases can be resolved according to the agreement. The police, as the first institution in the law enforcement process, had already issued regulations regarding the application of restorative justice, as a form of law enforcement efforts to change retributive law enforcement. The purpose of this research judicially examined the regulation of restorative justice at the police investigation phase in line with the enactment of the regulation of the Chief of Police Number: SE/8/VII/2018 concerning the Application of Restorative Justice in the Settlement of Criminal Cases and the Regulation of the Chief of the Indonesian Police Number 6 of 2019 concerning Criminal Investigation. This research used a qualitative research method with the type of normative legal research through a statutory approach
\end{abstract}

Keywords: victim, offender, police, restorative

\section{PENDAHULUAN}

Sebagaiman diketahui, kepolisian merupakan gerbang pertama dan utama dalam proses penegakan hukum. Setiap perkara yang dilaporkan ke kepolisian, akan melalui tahapan-tahapan penyelesaian perkara sesuai mekanisme yang sudah baku. Yaitu sebagaimana yang diatur di dalam hukum acara pidana UU Nomor 8 Tahun 1981 tentang Kitab Undang-undang Hukum Acara Pidana selanjutnya disebut KUHAP. Setiap tahapan dalam penegakan hukum akan melibatkan sub sistem peradilan pidana. Seiring berjalannya waktu, proses penegakan hukum dalam rangka penyelesaian perkara pidana tersebut menyisakan berbagai permasalahan. Antara lain, tumpukan perkara di hampir sub sistem peradilan dan proses penyelesaian perkara yang dianggap tidak memberikan keadilan kepada korban tindak pidana.

Dalam perkara pidana, penetapan seseorang menjadi tersangka, kemudian menjadi terdakwa dan dijatuhkan hukuman sesuai dengan tindak pidana yang dilakukan melalui proses yang secara garis besar melibatkan lembaga kepolisian, kejaksaan dan kehakiman. Secara umum penyidikan dilakukan di kepolisian dan penuntutan dilakukan oleh kejaksaan. ${ }^{1}$

Banyaknya perkara yang dilaporkan ke kepolisian membuat tumpukan perkara dalam tahapan penyelidikan ataupun penyidikan. Apabila semua perkara yang masuk ke kepolisian harus dilimpahkan ke kejaksaan maka tentu tumpukan perkara tersebut akan berpindah ke kejaksaan, demikian juga seterusnya. Penyelesaian perkara dalam tahapan penyelidikan ataupun penyidikan masih dianggap bukan bagian dari proses penegakan hukum. Perkara yang dilimpahkan ke Kejaksaan lah yang kemudian dianggap selesai di Kepolisian. Namun, dalam perkembangannya,

${ }^{1}$ Nella Octaviany Siregar, "Plea Bargaining dalam Sistem Peradilan Pidana di Beberapa Negara", Jurnal Wajah Hukum, 3 (1)(2019: hlm 1-9. 
proses penegakan hukum dengan mekanisme tersebut dianggap belum memberikan keadilan bagi para pihak, terutama korban tindak pidana.

Fenomena tersebut tentu saja telah menyebabkan arus perkara yang mengalir melalui pengadilan (baik itu dalam tingkat Pengadilan Negeri, Pengadilan Tinggi maupun pada tingkat Mahkamah Agung) melaju dengan sangat cepat sehingga terjadi penumpukan perkara. ${ }^{2} \mathrm{Hal}$ itu disebabkan arus masuk perkara ke kepolisian yang hampir semua harus dilimpahkan ke tahapan selanjutnya. Mekanisme ini yang kemudian dikenal dengan sebutan retributive justice.

Hadirnya restorative justice dianggap dapat menggantikan retributive justice yang selama ini terlalu kaku dan formalistik. Dalam perkara pidana, restorative justice akan lebih efektif sebagai alat untuk penyelesaian konflik. Dalam penegakan hukum pidana, keadilan itu harus diperoleh melalui tahapan sistem peradilan pidana sehingga itu tidak menutup kemungkinan untuk menerapkan keadilan restoratif dalam semua tahapan sistem peradilan pidana. ${ }^{3}$

Dalam pengaturan hukum positif, tentang restorative justice baru diatur di dalam UU No 11 Tahun 2012 tentang Sistem Peradilan Pidana Anak. Pengaturan tersebut masih bersifat parsial, hanya berlaku untuk anak pelaku atau anak yang berhadapan dengan hukum.

Undang Undang Sistem Peradilan Pidana Anak ini telah mengedepankan pendekatan restorative justice dan proses diversi sebagai upaya penyelesaian tindak pidana yang dilakukan oleh anak, sehingga penerapan restorative justice akan menawarkan jawaban atas isu-isu penting dalam penyelesaian perkara pidana. Yaitu, pertama kritik terhadap sistem peradilan pidana yang tidak memberi kesempatan khususnya bagi korban. Kedua, menghilangkan konflik khususnya antara pelaku dengan korban dan masyarakat. Ketiga, bahwa fakta dan perasaan ketidakberdayaan yang dialami sebagai akibat dari tindak pidana harus diatasi untuk mencapai perbaikan. ${ }^{4}$

Pengaturan restorative justice saat ini tidak hanya terdapat di Undang-undang Sistem Peradilan Pidana Anak, melainkan telah juga diatur di peraturan-peraturan yang lain. Semisal kepolisian, kejaksaan, dan lingkungan peradilan.

Kepolisian yang merupakan sub sistem peradilan pidana tingkat pertama merespon adanya issue keadilan restoratif dalam menyelesaikan perkara pidana dengan mengeluarkan Surat Edaran Nomor: SE/8/VII/2018 tentang Penerapan Keadilan Restoratif (Restorative Justice) dalam Penyelesaian Perkara Pidana dan Peraturan Kepolisian Nomor 6 Tahun 2019 tentang Penyidikan Tindak Pidan, keduanya a merupakan pengaturan terkait dengan restorative justice di kepolisian.

Pengaturan restorative justice di tingkat kepolisian ini menarik untuk dikaji mengingat jika berhasil dalam penanganan perkara akan berdampak kembalinya keseimbangan di masyarakat dengan cepat akibat kejahatan tanpa harus bertele-tele melalui mekanisme sistem peradilan pidana yang panjang, memakan waktu dan biaya.

Tulisan ini akan mengkaji restorative justice di Kepolisian dengan menelaah Surat Edaran Nomor: SE/8/VII/2018 tentang Penerapan Keadilan Restoratif (Restorative Justice) dalam Penyelesaian Perkara Pidana dan Peraturan Kepolisian Nomor 6 Tahun 2019 tentang Penyidikan Tindak Pidana.

\section{METODE}

Metode yang digunakan adalah kualitatif dengan jenis penelitian hukum normative. Pendekatan yang dilakukan adalah pendekatan perundang-undangan. Rancangan kegiatannya akan menelaah secara yuridis pengaturan restorative justice, baik itu berupa syarat formill atau materil di tahap kepolisian. Ruang lingkup atau objek penelitiannya adalah restorative justice dalam Surat Edaran Nomor: SE/8/VII/2018 tentang Penerapan Keadilan Restoratif (Restorative Justice) dalam Penyelesaian Perkara Pidana dan Peraturan Kepolisian Nomor 6 Tahun 2019 tentang Penyidikan Tindak Pidana. Teknik pengambilan data menggunakan studi pustaka lalu akan dianalisis menggunakan deskriptif analitis.

Definisi operasional dari variable penelitian yaitu:

1. Kepolisian adalah sub sistem peradilan pidana yang memiliki kewenangan untuk melakukan penyelidikan dan penyidikan suatu tindak pidana

2. Restorative justice adalah penyelesaian perkara pidana dengan melibatkan korban, pelaku dan masyarakat agar terwujud keadilan yang diinginkan

3. Telaah yuridis adalah kegiatan menelaah peraturan perundang-undangan

\footnotetext{
${ }^{2}$ Kristian\& Christine Tanuwijaya, "Penyelesaian Perkara Pidana Dengan Konsep Keadilan Restoratif (Restorative Justice) Dalam Sistem Peradilan Pidana Terpadu Di Indonesia”, Jurnal Mimbar Justitia, Vol. I No. 02 (Edisi Juli-Desember2015): Hlm 593.

3 Rena Yulia, "Penerapan Keadilan Restoratif Dalam Putusan Hakim:Upaya Penyelesaian Konflik Melalui Sistem Peradilan Pidana", Jurnal Yudisial, Vol. 5 No. 2 (Agustus 2012): 224 -240, Hlm 234.

${ }^{4}$ Ryan Aditama dan Novia Yolanda, "Penerapan Restorative Justice pada Peradilan Pidana Anak Terkait Pembaharuan Hukum Pidana di Indonesia”, Wajah Hukum, Volume 4 (2), (Oktober 2020): Hlm 491
} 


\section{HASIL DAN PEMBAHASAN}

\section{Kajian Restorative Justice di Kepolisian (Telaah terhadap Surat Edaran Nomor: SE/8/VII/2018 tentang Penerapan Keadilan Restoratif (Restorative Justice) dalam Penyelesaian Perkara Pidana)}

Lembaga Kepolisian memiliki tiga fungsi utama, yaitu fungsi pengayoman (perlindungan), fungsi pelayanan dan fungsi penegakan hukum. Dalam hal pelaksanaan fungsi penegakan hukum lembaga ini sangat terikat dengan prosedural yang telah ditetapkan, baik dalam perundang-undangan organiknya, maupun dalam hukum acara pidana yang berlaku umum serta keterikatan yang kuat pula dengan kebijakan-kebijakan yang ditetapkan oleh pimpinan institusi (keputusan atu pedoman atau surat perintah kapolri). ${ }^{5}$

Dalam fungsi penegakan hukum yang dilihat adalah penegakan peraturan perundang-undangan. Oleh karenanya, seringkali melupakan dari tujuan hukum itu sendiri, yaitu keadilan, kepastian hukum dan kemanfaatan. Proses penegakan hukum yang retributive lebih melihat pada kejahatan yang merupakan pelanggaran terhadap Negara, bukan pelanggaran terhadap individu. Focus pada penghukuman pelaku, lupa pada pemulihan korban akibat tindak pidana. Hal inilah yang kemudian menimbulkan kondisi keterabaian korban dalam proses penegakan hukum selama ini.

Konsep restorative justice merupakan bagian dari suatu pendekatan yang menitikberatkan terhadap keadaan menciptakan keadilan dan keseimbangan baik terhadap pelaku yang melakukan perbuatan pidana dan juga bagi hakhak korban. Prosedur maupun tatacara serta peradilan pidana yang berdasarkan asas pemidanaan diubah kearah proses penyelesaian secara kekeluargaan serta mediasi hingga tercapai kesepakatan. Penyelesaian perkara pidana tersebut memberikan keadilan yang seimbang bagi pihak korban maupun terhadap pelaku tindak pidana. ${ }^{6}$

Sebagai sub sistem peradilan pidana, kepolisian menanggapi restorative justice sebagai sebuah upaya penyelesaian konflik di tahap pertama. Dengan harapan tidak akan banyak perkara yang dilimpahkan ke kejaksaan karena dapat diselesaikan secara kekeluargaan di tingkat kepolisian antara pelaku dan korban serta masyarakat. Pengaturan restorative justice ini diatur di dalam Surat Edaran Nomor: SE/8/VII/2018 tentang Penerapan Keadilan Restoratif (Restorative Justice) dalam Penyelesaian Perkara Pidana dan Peraturan Kepolisian Nomor 6 Tahun 2019 tentang Penyidikan Tindak Pidana.

Surat Edaran menyatakan bahwa prinsip restorative justice merefleksikan keadilan sebagai bentuk keseimbangan manusia, sehingga perilaku menyimpang dari pelaku kejahatan dinilai sebagai perilaku yang menghilangkan keseimbangan. Surat Edaran juga menganggap bahwa restorative justice adalah upaya mengembalikan keseimbangan tersebut dengan membebani kewajiban terhadap pelaku kejahatan dengan kesadarannya mengakui kesalahan, meminta maaf, dan mengembalikan kerusakan dan kerugian korban seperti semula atau setidaknya menyerupai kondisi semula yang dapat memenuhi rasa keadilan korban.

Melihat prinsip restorative justice yang dianut oleh Surat Edaran tersebut, maka dapat diketahui bahwa Surat Edaran menginginkan restorative justice sebagai salah satu model penyelesaian perkara yang dapat dilakukan oleh pihak kepolisian. Yaitu dengan cara memulihkan keseimbangan yang sebelumnya telah dirusak oleh perilaku pelaku. Pengembalian kerusakan bisa berupa ganti rugi yang diberikan kepada korban.

Model restorative justice ini diterapkan sebagai bagian dari upaya penegakan hukum yang dilakukan dalam kerangka menangani timbulnya berbagai permasalahan dalam proses penegakan hukum pidana di Indonesia. Seperti Lembaga Pemasyarakatan yang over capacity, tunggakan perkara, jumlah penegakan hukum yang tidak seimbang, biaya perkara yang tidak mendukung yang kesemuanya berdampak pada pandangan masyarakat terhadap penegak hukum itu sendiri.

Namun, dalam Surat Edaran juga disebutkan bahwa penerapan prinsip restorative justice dalam konsep penyidikan dan penyelidikan tindak pidana dilakuan untuk kepentingan umum dan rasa keadilan masyarakat. Akan tetapi tidak bisa dimaknai sebagai metode penghentian perkara secara damai, melainkan lebih luas pada pemenuhan rasa keadilan semua pihak yang terlibat dalam perkara pidana. Hal itu dilakukan dengan upaya melibatkan korban, pelaku dan masyarakat setempat serta penyelidik atau penyidik sebagai mediator.

Mengenai penyelesaian perkara dapat dibuat dalam bentuk perjanjian perdamaian dan pencabutan hak menuntut dari korban. Yaitu dengan dimintakan penetapan hakim melalui jaksa penuntut umum untuk menggugurkan kewenangan menuntut dari korban dan penuntut umum.

Prinsip restorative justice yang dianut oleh Surat Edaran telah sesuai dengan pengertian restorative justice yang dikemukakan oleh banyak ahli. Yaitu untuk memulihkan keseimbangan, dengan cara melibatkan korban, pelaku, masyarakat dan mediator. Akan tetapi hal itu tidaklah secara serta merta dapat mencegah penumpukan perkara dan over capacity. Karena sesungguhnya tujuan dari restorative justice itu adalah memperbaiki hubungan bukan mencegah penghukuman.

5 S. Sahabudin, "Karakteristik Hukum Otonom dan Implikasinya di Indonesia (Model Penegakan Hukum Prosedural Pada Sistem Peradilan Pidana)", Wajah Hukum, Volume 1 Nomor 1, (Oktober 2017): Hlm 116.

${ }^{6}$ Ryan Aditama dan Novia Yolanda, opcit: Hlm 484. 
Sesungguhnya sudah tepat Surat Edaran mengatakan bahwan restorative justice tidak boleh dimaknai sebagai penghentian perkara secara damai, akan tetapi ketika salah satu cara yang dianjurkan adalah perjanjian perdamaian, maka hal tersebut dalam implementasinya menjadi bermakna ganda. Apalagi perdamaian itu harus dimintakan kepada hakim melalui jaksa penuntut umum untuk menggugurkan hak menuntut dari korban. Akan menjadi ironi dan ambiguitas dalam penegakan hukum.

Hal lain adalah, terkait dengan Polisi penyidik/penyelidik memiliki fungsi sebagai mediator dalam penerapan keadilan restoratif. Cara kerjanya sesuai dengan model-model restoratif justice yang dikenal selama ini, seperti Victim Offender Mediation atau lebih dikenal dengan sebutan VOM. Bentuk ini merupakan bentuk pendekatan restorative justice dimana dibuat suatu forum yang mendorong adanya pertemuan antara pelaku dan korban yang dibantu oleh mediator sebagai coordinator dan fasilitator dalam pertemuan tersebut. Bentuk ini dirancang untuk mencari kebutuhan yang menjadi prioritas korban khususnya kebutuhan untuk didengar keinginan-keinginan mengenai bentuk tanggungjawab pelaku, kebutuhan akan pengobatan atau pendampingan bagi korban, keinginan korban untuk didengarkan oleh pelaku terhadap dampak tindak pidana bagi kedua pihak dan berdiskusi tentang penanganan, usaha perbaikan dari dampak yang diderita oleh keduanya. ${ }^{7}$

Dalam pertemuan tersebut korban diminta menggambarkan pengalamannya berkaitan dengan tindak pidana yang dialaminya dan efek yang ditimbulkannya. Sementara pelaku menjelaskan tindak pidana apa yang telah dilakukannya dan mengapa tindak pidana itu dilakukan, serta menjelaskan segala pertanyaan korban berkaitan dengan hal tersebut. Sementara dialog antara korban dan pelaku, mediator memberikan berbagai masukan bagi tercapainya penyelesaian terbaik yang mungkin dilakukan.

Dalam praktek, polisi sebagai mediator sangat dimungkinkan, akan tetapi terdapat karakteristik kasus yang dapat dimediasi oleh polisi. Yaitu mediasi dilakukan pada kasus Kekerasan Dalam Rumah Tangga (KDRT), kasus yang melibatkan Anak, maka disitu polisi sebagai mediator. Pelaksanaannya harus ada pernyataan dari korban tentang bersedia untuk dimediasi, harus ada pengakuan bersalah dari anak pelaku, kemudian duduk bersama antara pihak pelaku dan pihak korban. Di luar kasus yang melibatkan Anak, mediasi dapat dilakukan untuk memfasilitasi kepentingan umum.

Selain itu, fungsi penyidik sebagai mediator juga harus dilakukan oleh penyidik yang memang telah mengikuti dan lulus menjadi mediator. Dalah hal perkara diselesaikan melalui mediasi penal misalnya, bahwa dalam mediasi penal ini diadakan rekonsiliasi dan pembayaran ganti kerugian kepada korban. Mediasi ini jika mencapai kesepakatan maka hasilnya dapat digunakan sebagai alasan untuk menghapuskan menjalankan pidana bagi pelaku tindak pidana. Mediator pada tahap ini bisa dilakukan oleh hakim ataupun mediator dari luar pengadilan yang telah mendapatkan sertifikasi dan pelatihan. ${ }^{8}$

Hal yang mendasar dari Restorative Justice adalah sukarela, oleh karenanya sukarela menjadi syarat utama untuk tercapainya perdamaian. Salah satunya bersedia untuk membayar. Kata sanggup untuk membayar juga disebutkan dalam form surat penghentian penyidikan berdasarkan restorative justice. Meskipun di sisi lain, kata sanggup membayar dapat diartikan sebetulnya perkara belum selesai, karena baru sanggup membayar, bukan telah membayar. Oleh karenanya pasti akan ada penilaian penyidik yang sifatnya subjektif terhadap suatu kasus yang sedang ditangani. Dari penilaian yang dilakukan penyidik, dapat ditentukan apakah kasus tersebut dapat diselesaikan dengan damai atau diteruskan secara due process of law.

Surat Edaran mengatur mengenai syarat diterapkannya restorative justice dalam sebuah perkara. Yaitu adanya syarat materil dan syarat formil.

Syarat materil mengatur bahwa perbuatan tersebut tidak menimbulkan keresahan masyarakat dan tidak ada penolakan masyarakat dan tidak berdampak konflik sosial. Hal ini masih multi tafsir, mengingat menimbulkan kersahan dan konflik sosial tidak ada standar baku. Ada perbuatan yang menimbulkan keresahan tetapi masih bisa diselesaikan diluar pengadilan, misalnya tawuran antar kampung.

Ada 9 prioritas yang menurut Muladi dapat diterapkan restorative justice. Skala prioritas pelaku tindak pidana dan jenis tindak pidana yang dapat dimasukkan dalam skema proses keadilan restoratif adalah pelaku pemula (first-time offender) bukan recidivis dalam tindak pidana sebagai berikut:

1. Tindak pidana anak;

2. Juvenile offenders;

3. Tindak pidana kealpaan;

4. Tindak pidana pelanggaran;

5. Tindak pidana yang diancam dengan pidana penjara di bawah lima tahun;

6. Tindak pidana ringan;

${ }^{7}$ Eva Achjani Zulfa, Pergeseran Paradigma Pemidanaan, (Bandung: Lubuk Agung, 2011), hlm 90-92.

8 Andri Winjaya Laksana, "Keadilan Restoratif Dalam Penyelesaian Perkara Anak Yang Berhadapan Dengan Hukum Dalam Sistem Peradilan Pidana Anak", Jurnal Pembaharuan Hukum, Volume IV No. 1 (Januari - April): 2017, Hlm 62. Doi: Http://Dx.Doi.Org/10.26532/Jph.V4i1.1644 
Dengan demikian perlu ditegaskan dalam Surat Edaran terkait jenis tindak pidana apa saja yang dapat diselesaikan dengan restorative justice. Hal itu agar dalam penerapannya tidak membingungkan penyidik sebagai pelaksana dalam proses penegakan hukum. Istilah ataupun penyebutan jenis tindak pidana sebaiknya disesuaikan dengan istilah di dalam peraturan perundang-undanganan. KUHP ataupun RUU KUHP dan UU lain yang mengatur secara khusus.

Syarat selanjutnya adalah adanya pernyataan dari semua pihak yang terlibat untuk tidak keberatan, dan melepaskan hak menuntutnya di hadapan hukum. Syarat materiil tersebut di atas dipahami/dimaknai bukan sebagai syarat materiil, melainkan seyogianya sebagai syarat formil dalam penyelesaian perkara pidana dengan penerapan keadilan restoratif; Frasa "semua pihak" terlalu luas dan bersifat multitafsir, seyogianya Surat Edaran menyebutkan dengan tegas dan limitatif mengenai siapa-siapa yang dikategorikan sebagai pihak yang terlibat untuk tidak keberatan, dan melepaskan hak menuntutnya di hadapan hukum.

Selain dari jenis tindak pidana, juga terdapat persyaratan dari pelaku tindak pidananya, yaitu pada pelaku:

1. tingkat kesalahan pelaku relatif tidak berat, yakni kesalahan (schuld atau mensrea dalam bentuk kesengajaan (dolus atau opzet) terutama kesengajaan sebagai maksud atau tujuan (opzet als oogmerk);

2. pelaku bukan residivis

Prinsip pembatas pada pelaku ini sedikit membingungkan, disisi lain disebutkan kesalahan pelaku relative tidak berat akan tetapi dijelaskan bahwa hal itu terkait dengan kesengajaan dengan maksud atau tujuan. Padahal diketahui bahwa kesengajaan dengan maksud merupakan kesalahan yang dianggap berat. Oleh karenanya, kesalahan yang seperti apa yang dapat diupayakan dengan menggunakan restorative justice di kepolisian. Tentu ini akan memperjelas bentuk kesengajaan mana yang menjadi kriteria tindak pidana yang dapat dilakukan restorative justice.

Prinsip pembatas yang kedua adalah pelaku bukan residivis. Jika melihat definisi dalam hukum pidana, residivis adalah orang yang melakukan kejahatan secara berulang, sudah divonis oleh hakim bersalah, menjalani hukuman, bebas, kemudian melakukan kejahatan yang sama. dalam praktek Restorative Justice, diperlukan pemahaman yang berbeda mengenai residivis. Tidak menutup kemungkinan, orang yang sudah pernah dilaporkan, kemudian diselesaikan dengan cara restorative justice, dalam arti tidak due process of law, suatu ketika dilaporkan lagi, baik dengan kejahatan yang sama atau pun kejahatan yang berbeda, maka apakah dapat disebut residivis dalam konteks penyelesaian restorative justice. Oleh karena itu, mungkin akan lebih tepat kalau menggunakan istilah repeat offender yaitu pengulangan tindak pidana oleh pelaku. Sehingga repeat offender tidak dapat lagi menempuh penyelesaian dengan pendekatan keadilan restoratif. Karena di lapangan, seringkali terjadi pelaku yang sudah melakukan kejahatan berulang tetapi tidak sampai ke pengadilan. Dengan kata lain perlu penjelasan residivis dalam Restorative Justice dengan penjelasan definisi residivis dalam hukum pidana. Sehingga dapat melindungi penyidik yang berhadapan langsung dengan masyarakat.

Selanjutnya terkait waktu pelaksanaan restorative justice. Diatur bahwa dapat dilaksanakan pada tahap penyelidikan; dan penyidikan sebelum SPDP dikirim ke Penuntut Umum. Pengaturan ini memberikan waktu yang sempit dalam pelaksanaan Restorative Justice. Waktu 7 hari tidak cukup untuk melakukan penyelesaian perkara pidana di luar pengadilan. Dalam waktu 7 hari belum tentu ada kesepakatan antara pelapor dan terlapor, masih diperlukan pemeriksaan saksi-saksi dan hal-hal lain yang harus dilakukan terkait proses penyidikan. Padahal biasanya pelaksanaaan perdamaian muncul kalau sudah dilakukan pemeriksaan saksi-saksi. Oleh karenanya waktu ini terlalu sempit untuk menerapkan Restorative Justice.

Sebaiknya waktu dibatasi sampai tahap dua, yaitu penyerahan tersangka dan barang bukti. Sehingga memiliki cukup waktu untuk menyelesaikan perkara pidana dengan menggunakan Restorative Justice. Oleh karenanya akan lebih longgar waktunya jika setelah penetapan tersangka.

Dengan demikian, tidak perlu dibatasi pada tahap penyidikan sebelum SPDP dikirim ke Penuntut Umum, melainkan sampai pada tahap 2. Jikalau dibatasi sampai tahap penyidikan, maka tidak akan cukup waktu untuk melakukan perdamaian dengan restorative justice. Seharusnya dioptimalkan saja pada tahap penyelidikan. Pada tahap penyidikan, untuk menghentikan perkara ada cara SP3, tidak perlu restorative justice. Pengaturan ini malah menunjukkan keragu-raguan atas mekanisme restorative justice yang akan diterapkan.

Namun demikian, untuk mensiasati waktu pengiriman SPDP yang singkat, maka dapat digunakan dengan cara tidak diterbitkan dulu sprindik nya agar perkara dapat selesai dalam masa penyelidikan dan leluasa dalam menerapkan proses restorative justice.

Mengenai syarat formil, Surat Edaran mengatur sebagai berikut:

1. Surat permohonan perdamaian kedua belah pihak (pelapor dan terlapor)

2. Surat pernyataan perdamaian (akte dading) dan penyelesaian perselisihan para pihak yang berperkara (pelapor, dan/atau keluarga pelapor, terlapor dan/atau keluarga terlapor dan perwakilan dari tokoh masyarakat) diketahui oleh atasan Penyidik; 
3. Berita acara pemeriksaan tambahan pihak yang berperkara setelah dilakukan penyelesaian perkara melalui keadilan restoratif;

4. Rekomendasi gelar perkara khusus yang menyetujui penyelesaian keadilan restoratif; dan

5. Pelaku tidak keberatan dan dilakukan secara sukarela atas tanggung jawab dan ganti rugi.

Mengkaji syarat formil di atas, ada hal yang menarik, yaitu adanya permohonan perdamaian dari kedua belah pihak lalu dibuatkan surat pernyataan perdamaian yang diketahui oleh atasan penyidik. Tetapi harus dibuatkan berita acara bahwa perkara tersebut telah selesai melalui restorative justice. Hal ini menyiratkan bahwa restorative justice dianggap sebagai model penyelesaian perkara. Sedangkan perdamaian sebagai salah satu syarat dapat dilakukannya restorative justice. Disebutkan pula terkait dengan adanya kesukarelaan dan tanggung jawab pelaku dalam memberikan ganti rugi. Namun tidak secara spesifik harus dimuat dalam berita acara ataupun pernyataan perdamaian.

Terkait dengan mekanisme dan alasan penghentian kasus dengan restorative justice diatur pula dalam Surat Edaran. Sebagai berikut:

1. setelah menerima permohonan perdamaian kedua belah pihak (pelapor dan terlapor) yang ditandatangani di atas materai, lakukan penelitian administratif syarat formil penyelesaian perkara melalui keadilan restoratif (Restorative Justice);

2. permohonan perdamaian setelah persyaratan formil terpenuhi diajukan kepada atasan penyidik untuk mendapat persetujuan;

3. setelah permohonan disetujui oleh atasan penyidik (Kabareskrim/ Kapolda/Kapolres), kemudian ditetapkan waktu pelaksanaan penandatangan pernyataan perdamaian;

4. pelaksanaan konferensi yang menghasilkan perjanjian kesepakatan yang ditandatangani semua pihak yang terlibat;

5. membuat nota dinas kepada pengawas penyidik atau Kasatker perihal permohonan dilaksanakan gelar perkara khusus untuk tujuan penghentian perkara;

6. melaksanakan gelar perkara khusus dengan peserta pelapor, dan/atau keluarga pelapor, terlapor dan/atau keluarga terlapor dan perwakilan dari tokoh masyarakat yang ditunjuk oleh penyidik, penyidik yang menandatangani dan perwakilan dari fungsi pengawas internal dan fungsi hukum dan unsur pemerintah bila diperlukan;

7. menyusun kelengkapan administrasi dan dokumen gelar perkara khusus serta laporan hasil gelar perkara;

8. menerbitkan Surat Perintah Penghentian Penyelidikan/Penyidikan dan Surat Ketetapan Penghentian Penyelidikan/Penyidikan dengan alasan Restorative Justice.

9. untuk perkara pada tahap penyelidikan, penyelidik menerbitkan Surat Perintah Penghentian Penyelidikan dan Surat Ketetapan Penghentian Penyelidikan yang ditandatangani oleh:

a. Direktur Reserse Kriminal pada tingkat Mabes Polri;

b. Direktur Reserse Kriminal pada tingkat Polda;

c. Kapolres, pada tingkat Polres dan Polsek.

10.untuk perkara pada tahap penyidikan, penyidik menerbitkan Surat Perintah Penghentian Penyedikan dan Surat Ketetapan Penghentian Penyedikan yang ditandatangani oleh:

a. Direktur Reserse Kriminal pada tingkat Mabes Polri;

b. Direktur Reserse Kriminal pada tingkat Polda;

c. Kapolres, pada tingkat Polres dan Polsek.

11.mencatat ke dalam buku register baru B-19 sebagai perkara keadilan restoratif (restorative justice) dihitung sebagai penyelesaian perkara.

Dalam form yang menjadi lampiran Surat Edaran, alasan dihentikannya penyidikan dikarenakan diselesaikan perkara tersebut dengan keadilan restoratif. Kata penghentian penyidikan ini menjadi bertentangan dengan KUHAP. Alasan penghentian penyidikan dengan diselesaikan restorative justice, tidak sesuai dengan alasan penghentian penyidikan yang diatur dalam pasal 109 KUHAP. Oleh karena itu, sebaiknya tidak perlu disebutkan alasan penghentian penyidikan adalah restorative justice dalam format penghentian penyidikan. Karena format penghentian tersebut kontradiktif dengan pasal 7 ayat (1) huruf e tentang diskresi kepolisian. Memang Diskresi merupakan semangat dari penyelesaian restorative justice, akan tetapi tidak perlu dituangkan dalam format penghentian penyidikan, agar tidak bertentangan dengan pasal 109 KUHAP. Kemudian dapat masuk dalam buku register perkara B-19 sebagai perkara yang sudah selesai.

Dengan selesainya perkara di tingkat kepolisian melalui restorative justice, maka akan tercapai tujuan awal yaitu mengurangi tumpukan perkara, mencegah over capacity dan menekan biaya penegakan hukum. Meski demikian perlu diingat bahwa prinsip restorative justice adalah memulihkan keseimbangan, memperbaiki hubungan dan mewujudkan rasa keadilan masyarakat.

Melihat hasil telaahan terhadap surat edaran tersebut, dapat disimpulkan bahwa pengaturan restorative justice di tingkat kepolisian telah ada dan mengatur mengenai pengertian restorative justice sebagai penyelesaian perkara tanpa 
harus dimaknai sebagai penghentian kasus secara damai. Telah diatur mengenai syarat fomil dan materil dari jenis tindak pidana yang dapat dilakukan restorative justice juga dari aspek pelaku, yaitu terkait dengan residivis misalnya. Namun, pelaksanaan restorative justice di tingkat kepolisian ini dibatasi 7 hari sebelum diterbitkannya SPDP sehingga kemungkinan penyidik kesulitan untuk menerapkannya.

\section{Restorative Justice dalam Peraturan Kepolisian Nomor 6 Tahun 2019 tentang Penyidikan Tindak Pidana}

Dalam melaksanakan tugas penegakan hukum, penyidik kepolisian memiliki tugas, fungsi dan wewenang di bidang penyidikan tindak pidana sesuai dengan peraturan perundang-undangan, yang dilaksanakan secara profesional, transparan dan akuntabel terhadap setiap perkara pidana guna terwujudnya supremasi hukum yang mencerminkan kepastian hukum, rasa keadilan dan kemanfaatan.

Peraturan Kepolisian ini merupakan petunjuk teknis bagi para polisi dalam menjalankan penyidikan tindak pidana. Sebagaimana diketahui bahwa penyidikan merupakan serangkaian tindakan penyidik dalam hal dan menurut cara yang diatur dalam undang-undang untuk mencari serta mengumpulkan bukti yang dengan bukti itu membuat terang tentang tindak pidana yang terjadi dan guna menemukan tersangkanya.

Peraturan kepolisian ini mengatur hal yang baru dalam proses penegakan hukum. Yaitu memuat peraturan tentang restorative justice. Penyebutannya merujuk pada bahasa Indonesia, yaitu Keadilan Restoratif. Pasal 1 angka 27 menyatakan bahwa keadilan restoratif adalah penyelesaian kasus pidana yang melibatkan pelaku, korban dan/atau keluarganya serta pihak terkait, dengan tujuan agar tercapai keadilan bagi seluruh pihak.

Peraturan Kepolisian ini menegaskan bahwa restorative justice merupakan penyelesaian kasus pidana. Hal ini mengandung makna bahwa restorative justice merupakan salah satu cara yang ditawarkan dalam menyelesaikan perkara pidana di tingkat kepolisian. Penyelesaian perkara ini melibatkan pelaku, korban serta pihak terkait. Adapun tujuannya adalah tercapai keadilan untuk semua pihak tersebut.

Bila melihat pengertian restorative justice dari para ahli, sebut saja Howard Zehr. Ada beberapa hal penting yang membedakan antara retributive justice dan restorative justice, antara lain: ${ }^{9}$

Dalam Retributive Justice :

1. Kejahatan adalah pelanggaran sistem;

2. Fokus pada menjatuhkan hukuman;

3. Menimbulkan rasa bersalah;

4. Korban diabaikan;

5. Pelaku pasif;

6. Pertanggungjawaban pelaku adalah hukuman;

7. Respons terpaku pada perilaku masa lalu pelaku;

8. Stigma tidak terhapuskan;

9. Tidak didukung untuk menyesal dan dimaafkan;

10.Proses bergantung pada aparat;

11.Proses sangat rasional.

Dalam restorative justice:

1. Kejahatan adalah perlukaan terhadap individu dan/atau masyarakat;

2. Fokus pada pemecahan masalah;

3. Memperbaiki kerugian;

4. Hak dan kebutuhan korban diperhatikan;

5. Pelaku didorong untuk bertanggung jawab;

6. Pertanggungjawaban pelaku adalah menunjukkan empati dan menolong untuk memperbaiki kerugian;

7. Respons terpaku pada perilaku menyakitkan akibat perilaku pelaku;

8. Stigma dapat hilang melalui tindakan yang tepat,

9. Didukung agar pelaku menyesal dan maaf dimungkinkan untuk diberikan oleh korban;

10.Proses bergantung pada keterlibatan orang-orang yang terpengaruh oleh kejadian;

11.Dimungkinkan proses menjadi emosional.

Dari karakteristik restorative justice yang menurut Howard Zehr di atas, maka sebetulnya dapat dijadikan patokan dalam implementasi restorative justice di kepolisian. Misalnya dalam restorative justice harus fokus pada pemecahan masalah lalu memperbaiki kerugian. Sehingga hak dan kebutuhan korban itu harus diperhatikan, dan mendorong pelaku untuk bertanggungjawab. Bentuk pertanggungjawaban pelaku dapat berupa menunjukkan empati untuk memperbaiki kerugian yang diderita oleh korban.

${ }^{9}$ Rena Yulia, Viktimologi Perlindungan Hukum Terhadap Korban Kejahatan, Edisi 2, (Yogyakarta: Graha Ilmu, 2021), hlm 187. 
Tidak hanya korban, pelaku juga diperhatikan dengan berupaya menghilangkan stigma terhadap pelaku, pelaku dimungkinkan untuk meminta maaf dan menyatakan menyesal atas perbuatannya. Hal ini menjadi bagian penting kedua setelah bersedia memperbaiki kerugian korban. Meskipun dalam proses yang seperti ini dimungkinkan adanya proses yang emosional. Misalnya korban yang masih belum terima dengan kondisi akibat perbuatan pelaku, bisa melakukan hal-hal yang emosional, tidak hanya korban, keluarga korban juga bisa melakukan hal-hal yang emosional, termasuk pelaku atau keluarga juga dapat melakukan perbuatan yang emosional, misalnya tidak menerima kesalahan atau tidak mau minta maaf.

Disitulah peran kepolisian diperlukan dalam menyelesaikan persoalan yang terjadi antara pelaku dan korban dengan fokus pada pemecahan masalah. Peran penyidik dapat menjadi mediator yang dapat menjadi penengah untuk mencari solusi keadilan apa yang diinginkan oleh masing-masing pihak.

Mediasi bukanlah hal baru bagi Polri. Meskipun tidak semua perkara/permasalahan diselesaikan secara mediasi. Faktanya, Polri dalam bertindak menangani permasalahan yang terjadi di tengah-tengah masyarakat dapat melakukan mediasi baik dalam ruang lingkup tugas serse maupun lantas. ${ }^{10}$ Mediasi diyakini mendatangkan manfaat bagi petugas kepolisian, seperti terbangunnya pemahaman yang lebih baik tentang bagaimana berinteraksi dan berkomunikasi dengan pihak berkepentingan hukum maupun warga masyarakat. ${ }^{11}$

Pemaknaan keadilan restoratif sebagai penyelesaian kasus pidana menjadi rentan untuk diartikan sebagai proses perdamaian. Meskipun perdamaian menjadi salah satu syarat dalam surat edaran tetapi banyak yang salah paham dengan kata perdamaian dalam proses penegakan hukum. Bahkan kata selesai dengan damai pun seolah berbeda. Oleh karenanya sebetulnya tidak bisa diartikan secara langsung bahwa restorative justice adalah perdamaian. Melainkan restorative justice adalah cara untuk melakukan perdamaian antara pelaku dan korban.

Terkait pilihan untuk menerapkan pendekatan keadilan restoratif yang harus dilakukan secara sukarela, perdamaian sesungguhnya menjadi pintu masuk untuk dapat diterapkannya pendekatan ini. Selalu terdapat kemungkinan bahwa para pihak yang terlibat dalam suatu konflik atau sengketa dalam hal terjadinya tindak pidana memilih untuk melakukan perdamaian dan tidak melanjutkan proses hukum atas perkara tersebut. Perdamaian dapat dilakukan para pihak dengan melibatkan baik subsistem yang terdapat didalam maupun diluar sistem peradilan pidana. ${ }^{12}$

Selanjutnya Pasal 12 menyebutkan bahwa keadilan restoratif dapat dilakukan dalam proses penyidikan apabila memenuhi syarat materil dan syarat formil yang diatur di dalam perkap ini.

Secara rinci pengaturan tersebut sebagai berikut:

Dalam proses penyidikan dapat dilakukan keadilan restoratif, apabila terpenuhi syarat:

Materiel, meliputi:

1. Tidak menimbulkan keresahan masyarakat atau tidak ada penolakan masyarakat;

2. Tidak berdampak konflik sosial;

3. Adanya pernyataan dari semua pihak yang terlibat untuk tidak keberatan, dan melepaskan hak menuntutnya di hadapan hukum;

4. Prinsip pembatas:

a. Pada pelaku:

1) tingkat kesalahan pelaku relatif tidak berat, yakni kesalahan dalam bentuk kesengajaan; dan

2) pelaku bukan residivis;

b. Pada tindak pidana dalam proses:

1) penyelidikan; dan

2) penyidikan, sebelum SPDP dikirim ke Penuntut Umum;

Formil, meliputi:

1. Surat permohonan perdamaian kedua belah pihak (pelapor dan terlapor);

2. Surat pernyataan perdamaian (akte dading) dan penyelesaian perselisihan para pihak yang berperkara (pelapor, dan/atau keluarga pelapor, terlapor dan/atau keluarga terlapor dan perwakilan dari tokoh masyarakat) diketahui oleh atasan penyidik.

Adapun syarat materil dan syarat formil yang diatur dalam Peraturan Kapolri ini sama dengan syarat formil dan materil yang diatur di dalam Surat Edaran. Artinya dalam penerapan restorative justice masih menyulitkan bagi penyidik. Terutama permasalahan waktu yang diberikan dalam melakukan penyelesaian kasus dengan menggunakan restorative justice. Dalam prinsip pembatas, mensyaratkan restorative justice hanya dapat dicapai jika dilakukan

${ }^{10}$ Andrea H Poeloengan dkk, Mediasi dalam Fungsi Pengawasan Polri, ( Jakarta: Kompolnas, 2017), Hlm 10.

${ }^{11}$ Ibid, hlm 11

12 Nefa Claudia Meliala, "Pendekatan Keadilan Restoratif: Upaya Melibatkan Partisipasi Korban Dan Pelaku Secara Langsung Dalam Penyelesaian Perkara Pidana", Veritas Et Justitia, Volume 1 Nomor 1, (2015): Hlm 120. Doi Https://Doi.Org/10.25123/Vej.1419 
sebelum SPDP dikirimkan kepada penuntut umum. SPDP harus disampaikan dalam waktu 7 (tujuh) hari setelah diterbitkan Surat Perintah Penyidikan. Dengan demikian proses restorative justice harus selesai dalam waktu 7 (tujuh) hari juga, hal itu tentu sangat menyulitkan dalam implementasinya. Permasalahan kemudian adalah waktu 7 hari yang diberikan tidak akan cukup untuk menyelesaikan perkara pidana melalui restorative justice.

Putusan Mahkamah Konstitusi Nomor 130/PUU-XIII/ 2015 menyatakan bahwa waktu paling lambat 7 hari dipandang cukup bagi penyidik untuk mempersiapkan atau menyelesaikan hal tersebut. Pertimbangan ini didasarkan pada tertundanya penyampaian SPDP oleh penyidik kepada jaksa penuntut umum bukan saja menimbulkan ketidak pastian hukum akan tetapi juga merugikan hak konstitusional terlapor dan korban/pelapor. Alasan mahkamah didasarkan pertimbangan bahwa terlapor yang telah mendapatkan SPDP maka yang bersangkuan dapat mempersiapkan bahan-bahan pembelaan dan juga dapat menunjuk penasehat hukum yang akan mendampinginya, sedangkan bagi korban/pelapor dapat dijadikan momentum untuk mempersiapkan keterangan atau bukti yang diperlukan dalam pengembangan penyidikan atas laporannya. ${ }^{13}$

Pertimbangan mahkamah yang demikian dapat terlihat bahwa penyelesaian perkara hanya berorientasi pada mekanisme peradilan pidana selama ini yang bersifat retributive justice, belum mengarah pada penyelesaian perkara pidana dengan mendamaikan kedua belah pihak. Hal ini dapat dipahami karena KUHAP masih berorientasi pelaku dalam penegakan hukumnya.

Pada akhirnya, solusinya adalah keadilan restoratif dilakukan pada saat sebelum dilakukan penyidikan, yaitu pada tahap penyelidikan. Agar tidak terkena limit waktu 7 (tujuh) hari tersebut. Reformulasi substansi terkait batasan waktu ini perlu dilakukan, mengingat mekanisme restorative justice merupakan mekanisme yang khusus, sehingga tidak menjadi persoalan jika memiliki hukum acara yang khusus juga, asalkan diatur di dalam peraturan perundangundangan yang berlaku.

Reformulasi tersebut dilakukan untuk mewujudkan tujuan utama dari restorative justice yaitu perbaikan luka yang diakibatkan perbuatannya, dan konsiliasi serta rekonsiliasi di kalangan korban, pelaku dan masyarakat. ${ }^{14}$

Hal yang menjadi penting dalam melihat Surat Edaran dan Peraturan Kapolri adalah adanya pergeseran pemaknaan restorative justice itu sendiri. Pemulihan yang dimaksud dalam restorative justice adalah pemulihan korban dan pelaku. Atau disebut keseimbangan. Sehingga seharusnya ada penekanan pemulihan relasi korban dengan pelaku. Bukan hanya sekedar perdamaian dengan pemulihan korban melalui ganti rugi, melainkan adanya perbaikan hubungan antara korban dan pelaku. Pernyataan bersalah dan permintaan maaf menjadi bagian penting dalam upaya memulihkan keseimbangan. Karena sesungguhnya restorative justice bukan sekedar penghentian perkara secara damai, melainkan pemenuhan rasa keadilan bagi semua pihak. Baik itu korban, pelaku maupun masyarakat.

Apabila melihat pergeseran konsep dari retributive justice ke arah restorative justice, tentu tidak hanya sematamata dibatasi oleh mekanisme waktu yang begitu sempit (sebelum SPDP) melainkan memang orientasi dari sistem peradilan pidana juga harus bergeser. Bukan saja kepada pelaku tindak pidana, melainkan harus memberikan perhatian juga pada korban tindak pidana dan masyarakat.

Peraturan Kapolri No 6 Tahun 2019 ini merupakan aturan mengenai penyidikan tindak pidana, tentu saja didalamnya akan lebih banyak mengatur tentang pelaku, karena penyidikan dilakukan untuk menemukan tersangka, pelaku tindak pidana. Akan tetapi ketika ada pengaturan restorative justice di dalamnya, tentu tujuannya sudah bertambah, tidak saja menemukan tersangka lalu melakukan proses penegakan hukum melainkan ada hal baru yang dapat dilakukan dalam proses penegakan hukum yaitu melibatkan korban sebagai pihak yang dapat menentukan keadilan mana yang ingin diperoleh, bukan hanya sebagai saksi.

Perlu diingat, bahwa keadilan restoratif berpijak pada hubungan yang manusiawi antara korban dengan pelanggar dan dampak yang ditimbulkan oleh kejahatan pada semua pihak, bukan hanya pada korban, tetapi juga pada masyarakat dan pelanggar sendiri. Oleh sebab itu, dalam proses penegakan hukum yang bersendikan pada perspektif keadilan restoratif, kepolisian menjadi alat Negara untuk menyelesaikan perkara tersebut dengan melibatkan pelaku, korban dan juga masyarakat.

Selama ini, kepolisian menjalankan penegakan hukum dengan menggunakan falsafah retributif (pembalasan), fokus pada pelaku tanpa merasa perlu melibatkan korban. Perspektif retributive justice melanjutkan falsafah yang dianut oleh hukum pidana dan penyelenggaraan peradilan pidana sebelumnya. Lalu dengan adanya restorative justice tentu harus ada pergeseran, bahwa semula kejahatan adalah konflik antara pelanggar dengan korban yang diwakili oleh negara kemudian berkembang ke arah perspektif restorative justice yang menganggap kejahatan merupakan pelanggaran terhadap individu yang diakui sebagai konflik.

Dasar pijak perspektif restorative justice adalah bahwa konsep kejahatan adalah perbuatan yang melanggar pertama dan terutama adalah hak perseorangan (yaitu korban kejahatan); di samping melanggar masyarakat, negara dan kepentingan pelanggar itu sendirri. Oleh karenanya, pihak yang merasa telanggar haruslah dilibatkan dalam

\footnotetext{
${ }^{13}$ Putusan Mahkamah Konstitusi Nomor 130/PUU-XIII/2015, hlm 147.

${ }^{14}$ Nur Rochaeti, "Implementasi Keadilan Restoratif Dan Pluralisme Hukum Dalam Sistem Peradilan Pidana Anak Di Indonesia”, Masalah-Masalah Hukum, Volume 44 Nomor 2, (2015): Hlm 153. Doi: 10.14710/Mmh.44.2.2015.150-160
} 
penyelesaian perkara di tingkat kepolisian tersebut. Orang yang terlanggar haknya (korban kejahatan) adalah sebagai pertama yang berkepentingan. Dalam konteks ini, sub sistem peradilan pidana, yaitu kepolisian harus menempatkan kepentingan korban kejahatan sebagai kepentingan yang utama.

Sasaran dari proses peradilan pidana menurut perspektif Restorative justice adalah menuntut pertanggungjawaban pelanggar terhadap perbuatan dan akibat-akibatnya, yakni bagaimana merestorasi penderitaan orang yang terlanggar haknya (korban kejahatan) seperti pada posisi sebelum pelanggaran dilakukan atau kerugian terjadi, baik aspek materiil maupun aspek immateriil.

Penyelesaian konflik yang terjadi yang ditonjolkan bukan menegaskan kesalahan pelanggar kemudian menjatuhkan sanksi pidana, tetapi peran aktif pihak yang berkonflik melalui mediasi atau kompensasi terhadap kerugian materiil dan immateriil dalam bentuk restitusi atau kompensasi dan pemulihan keharmonisan hubungan kemanusiaan antar pihak-pihak (humanisasi). Orientasi peradilan pidana adalah untuk kehidupan di masa yang akan datang. Oleh sebab itu, penyelesaian di luar proses pengadilan dengan cara rekonsiliasi dan negosiasi dianjurkan menurut perspektif restorative justice dan tidak tertutup kemungkinan adanya lembaga permaafan dari korban kepada pelanggar.

Perdebatan tentang keadilan dalam pemidanaan yang tepat menggambarkan perbedaan antara perspektif keadilan retributif dan perspektif keadilan restoratif, baik keadilan prosedural maupun keadilan substantif.

Dengan adanya pengaturan restorative justice dalam peraturan di kepolisian, ini menjadikan polisi harus memperhatikan kondisi korban atau melibatkan korban dalam proses penegakan hukum. Tidak bisa lagi offender oriented melainkan harus juga victim oriented. Institusi kepolisian sebagai sub sistem pertama dalam proses penegakan hukum memiliki peran untuk melibatkan korban dalam proses penyelesaian perkara pidana. Keterlibatan korban kejahatan dalam proses peradilan pidana merupakan hal yang penting, sesuai dengan semanagat restorative justice itu sendiri.

Polisi dalam memandang restorative justice bukanlah semata-mata untuk menyelesaikan perkara secara damai demi kepentingan pelaku yang tidak mau diberikan sanksi atau menghindar dari pemidanaan, melainkan bertujuan membangun suatu sistem nilai tanggung jawab sosial. Mendorong pelaku untuk mengakui kesalahan dan menumbuhkan permaafan dari korban juga memulihkan kerugian korban.

Pergeseran konsep kejahatan dan orientasi hukum pidana yang telah diuraikan diatas, telah membawa harapan cerah untuk perlindungan hukum terhadap korban. Pergeseran dari retributive justice ke arah restorative justice memberikan dampak positif bagi pencegahan dan penanggulangan kejahatan.

Dari telaah yuridis surat edaran dan peraturan kepolisian, lebih banyak mengatur tentang hal-hal yang berkaitan dengan pelaku. Merupakan hal yang wajar mengingat peraturan ini memang dalam rangka penyidikan tindak pidana. Namun demikian, adanya pengaturan restorative justice dalam peraturan kepolisian haruslah diterjemahkan sebagai upaya penyelesaian konflik pidana yang terjadi antara pelaku dengan korban. Penyelesaian dimediasi oleh polisi dengan melibatkan berbagai pihak, yaitu pelanggar, korban, masyarakat. Penyelesaian dilakukan bukan semata-mata bertujuan untuk menjauhkan tersangka dari sanksi pidana atau menghindarkan pemidanaan bagi tersangka, melainkan yang utama adalah memulihkan kerugian korban, merekonsiliasi hubungan antar personal dan menyelesaikan konflik yang terjadi di masyarakat.

\section{SIMPULAN}

Telaahan terhadap pengaturan restorative justice di Kepolisian dilakukan dengan melakukan telaahan terhadap Surat Edaran Kapolri Nomor: SE/8/VII/2018 tentang Penerapan Keadilan Restoratif (Restorative Justice) dalam Penyelesaian Perkara Pidana dan Peraturan Kepala Kepolisian RI Nomor 6 Tahun 2019 tentang Penyidikan Tindak Pidana. Hasil telaahan diketahui terdapat pergeseran prinsip restorative justice dari penyelesaian perkara menjadi penghentian perkara. Proses penyelesaian masih berorientasi pada rangkaian tahapan yang harus dilakukan dan berakibat hukum bagi pelaku, bukan melibatkan kedua pihak (pelaku dan korban dalam menuju penyelesaian perkara dengan damai. Reformulasi prinsip pembatas ini harus fokus pada penyelesaian perkara pidana sebelum SPDP disampaikan kepada jaksa penuntut umum, bukan menghentikan perkara saja. Mekanisme proses penyelesaian perkara secara restorative justice harus diperbaiki secara prosedural agar tidak menghilangkan substansi dari tujuan restorative justice itu sendiri. Perbaikan secara prosedural yang mendasar terletak pada harus menambahkan tahapan dengar pendapat dari korban agar dapat mengetahui keinginan korban dan juga kesediaan pelaku dalam memulihkan kerugian. Perlu diingat, bahwa memulihkan keseimbangan, memperbaiki kerusakan, meminta maaf dan membangunn tanggungjawab sosial adalah lebih utama daripada sekedar menjauhkan pelaku dari hukuman dan pemidanaan. 


\section{DAFTAR PUSTAKA}

Aditama, Ryan dan Yolanda, Novia, "Penerapan Restorative Justice pada Peradilan Pidana Anak Terkait Pembaharuan Hukum Pidana di Indonesia", Jurnal Wajah Hukum Volume 4 (2), (Oktober 2020): Hlm 491

Kristian\& Christine Tanuwijaya, "Penyelesaian Perkara Pidana Dengan Konsep Keadilan Restoratif (Restorative Justice) Dalam Sistem Peradilan Pidana Terpadu Di Indonesia”, Jurnal Mimbar Justitia Vol. I No. 02 (Edisi Juli-Desember2015): Hlm 593.

Laksana, Andri Winjaya, "Keadilan Restoratif Dalam Penyelesaian Perkara Anak Yang Berhadapan Dengan Hukum Dalam Sistem Peradilan Pidana Anak", Jurnal Pembaharuan Hukum, Volume IV No. 1 (Januari - April 2017): Hlm 62. Doi: Http://Dx.Doi.Org/10.26532/Jph.V4i1.1644

Meliala, Nefa Claudia, "Pendekatan Keadilan Restoratif: Upaya Melibatkan Partisipasi Korban Dan Pelaku Secara Langsung Dalam Penyelesaian Perkara Pidana”, Veritas Et Justitia, Volume 1 Nomor 1, (2015): Hlm 120. Doi Https://Doi.Org/10.25123/Vej. 1419

Poeloengan, Andrea H, dkk, Mediasi dalam Fungsi Pengawasan Polri, Jakarta: Kompolnas, 2017.

Rochaeti, Nur, "Implementasi Keadilan Restoratif Dan Pluralisme Hukum Dalam Sistem Peradilan Pidana Anak Di Indonesia", Masalah-Masalah Hukum Volume 44 Nomor 2, (2015): Hlm $153 . \quad$ Doi: 10.14710/Mmh.44.2.2015.150-160

S. Sahabudin, "Karakteristik Hukum Otonom dan Implikasinya di Indonesia (Model Penegakan Hukum Prosedural Pada Sistem Peradilan Pidana)", Wajah Hukum, Volume 1 Nomor 1, (Oktober 2017): Hlm 116.

Siregar, Nella Octaviany, "Plea Bargaining dalam Sistem Peradilan Pidana di Beberapa Negara", Jurnal Wajah Hukum, 3 (1) (2019): hlm 1-9.

Yulia, Rena, "Penerapan Keadilan Restoratif Dalam Putusan Hakim:Upaya Penyelesaian Konflik Melalui Sistem Peradilan Pidana”, Jurnal Yudisial Vol. 5 No. 2 (Agustus 2012) : Hlm 234.

Yulia, Rena, Viktimologi Perlindungan Hukum Terhadap Korban Kejahatan, Edisi 2, Yogyakarta: Graha Ilmu, 2021.

Zulfa, Eva Achjani, Pergeseran Paradigma Pemidanaan, Bandung: Lubuk Agung, 2011. 